\title{
BOUGUER ANOMALIJŲ ŽEMĖLAPIO PATIKSLINIMAS GIS PRIEMONĖMIS
}

\author{
Saulius Šliaupa ${ }^{1}, \check{Z ̌ y d r u ̄ n a s ~ D e ̉ n a s ~}^{2}$, Larisa Korabliova ${ }^{3}$ \\ ${ }^{1}$ Geologjios ir geografijos institutas, T. Ševčenkos g. 13, LT-03223 Vilnius, Lietuva, el.paštas sliaupa@geo.lt \\ ${ }^{2}$ Vilniaus universitetas, Geologijos ir mineralogijos katedra, M. K. Čiurlionio g. 21/27, LT-03101 Vilnius, Lietuva \\ ${ }^{3}$ Lietuvos geologijos tarnyba, S. Konarskio g. 35, LT-03123 Vilnius, Lietuva
}

Iteikta 200501 26, priimta 20050314

\begin{abstract}
Santrauka. Gravitacinio lauko variacijas geriausiai atspindi Bouguer anomalijų žemėlapis, kurị sudarant, be kitų parametru, labai svarbu žinoti tarpinio sluoksnio, t. y. sluoksnio, esančio tarp Žemès paviršiaus ir jūros lygio, tankị. Pagal priimtą metodiką Lietuvos Bouguer anomalijų žemėlapis sudarytas įvedus pastovų $2,30 \mathrm{~g} / \mathrm{cm}^{3}$ tankị. Tačiau geologiniai tyrimai rodo, kad viršutiniams sluoksniams būdingas labai ryškus uolienų sudèties ir atitinkamai tankio kitimas, todèl dabar naudojamas gravitacinio lauko žemėlapis nėra visai tikslus. Anomalijų laisvajame ore ir aukščiu koreliacija rodo, kad vidutinis tarpinio sluoksnio tankis yra gerokai mažesnis (mažesnis nei $2,24 \mathrm{~g} / \mathrm{cm}^{3}$ ). Straipsnyje pateikiama nauja tarpinio sluoksnio tankių ịvertinimo, taikant GIS technologijas, metodika. Pagal iš 13222 gręžiniu gautą informaciją sudarytas detalus tankių žemèlapis. Šie duomenys automatiškai pervesti į gravitacinius stebėjimo taškus, atitinkamai perskaičiuotas Bouguer anomalijų žemėlapis. Masių deficitas, palyginti su ankstesniu tarpinio sluoksnio modeliu, kinta nuo $+10000 \mathrm{~kg} / \mathrm{m}^{2}$ Šiaurès Lietuvos centrinejje dalyje iki $-30000 \mathrm{~kg} / \mathrm{m}^{2}--50000 \mathrm{~kg} / \mathrm{m}^{2}$ didžiojoje Lietuvos dalyje. Atitinkamai gerokai pakoreguotos ir Bouguer anomalijų reikšmès. Skirtumas siekia net 23 mGal Baltijos aukštumose, 0,5-1 mGal Žemaitijos aukštumose ir -0,5 mGal Šiaurès Lietuvos centrinèje dalyje. Siūlomą metodiką galima plačiai taikyti ir kituose regionuose tikslinant gravitacinio lauko žemėlapius. Be to, tai leidžia koreguoti ir kitus gravitacinio lauko žemėlapius (pvz., nustatant geoida).
\end{abstract}

Raktažodžiai. Bouguer anomalija, gravitacinis laukas, GIS, tarpinio sluoksnio tankis.

\section{Ivadas}

Bouguer anomalijų žemėlapis, kuriame atsispindi Žemès gravitacinio lauko variacijos, yra sudaromas iš stebimo lauko, ịvedus gravitacinę korekciją dèl geografinès padèties, reljefo ir tarpinio sluoksnio, esančio tarp žemès paviršiaus ir nulinès linijos (jūros lygio), masių poveikio. Matavimo taško topografinè pataisa paprastai yra gerai žinoma, o tarpinio sluoksnio masių itaka dažniausiai nustatoma kaip konstanta visam regionui. Lietuvoje reljefo aukščių reikšmès kinta nuo 0 pajūryje iki beveik $300 \mathrm{~m}$ Lietuvos pietrytiniame kampe (1 pav.). Šio tarpinio sluoksnio litologija (atitinkamai ir tankis) yra labai kaiti. Dažniausiai tai labai sudètingos geologinès sandaros kvartero uolienos, kurios susidarè per pastaruosius kelis milijonus metų užslenkant ir atisitraukiant ledynams. Iki kelių šimtų metrų storymės litologinè sandara nedideliame plote gali keistis nuo moreniniu priemolių ir priesmèlių [1], kurių tankis viršija $2 \mathrm{~g} / \mathrm{cm}^{3}$, iki smèlinguju uolienu, kurių tankis yra $1,7-1,8 \mathrm{~g} / \mathrm{cm}^{3}$ (t. y. 15-20\% mažesnès reikšmès) [2]. Be to, virš nulinio paviršiaus neretai atsidengia ir prekvartero uolienos, kurių tankio kitimo intervalas dar didesnis (nuo $1,8-2,0 \mathrm{~g} / \mathrm{cm}^{3}$ smèlių, kreidos iki $2,8 \mathrm{~g} / \mathrm{cm}^{3}$ dolomitu).
Dabar naudojamas Lietuvos Bouguer anomaliju žemèlapis turi sistemingają paklaidą, susidarančią neįvertinus skirtingo masių pasiskirstymo tarpiniame sluoksnyje. Gi sprendžiant i̇vairias geologines, geodezines problemas reikia turèti kuo tikslesnius duomenis. Esant tokiai sudettingai geologinei situacijai kaip Lietuvoje, tankių korekcijai ịvesti reikia panaudoti visą turimą geologinę medžiagą (keliolika tūkstančių gręžiniu). Tai įmanoma padaryti tik taikant šiuolaikines GIS (Geografinès informacinès sistemos) kompiuterines priemones, kuriomis gerai išnaudojama duomenų bazèse sukaupta informacija.

Tarpinio sluoksnio tankių pasiskirstymui nustatyti taikomi ìvairūs metodai, dažniausiai naudojant tuos pačius gravitacinio lauko matavimų duomenis, gautus atlikus blokų laisvojo oro anomalijos ir aukščio linijinę regresinę analizę [3], gradientų matavimą [4], fraktalinę topografijos ir gravitacinio lauko analizę [5], gravitacinio lauko matavimus gręžiniuose [6]. Pastarieji plačiai taikomi kolektorių tyrimams, tačiau mažai tetinka Bouguer žemėlapiui tikslinti. Straipsnyje siūloma metodika skiriasi nuo minètujų, nes ji remiasi tiesiogine (gręžiniu) informacija, dèl to daug detalesnè nei paprastai taikoma geofizinè interpretacija. 


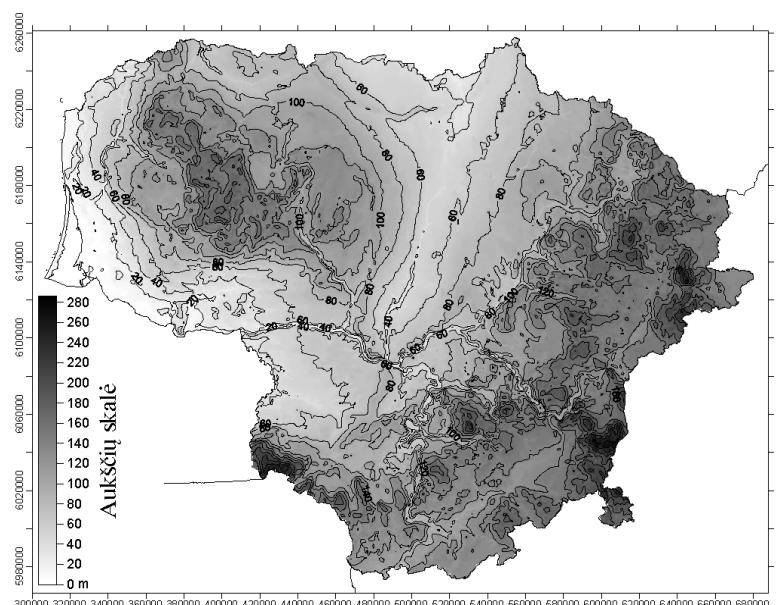

1 pav. Lietuvos reljefo aukščiu žemėlapis (skaitmeninis modelis)

Fig 1. Relief of Lithuania (digital terrain model)

\section{Duomenys ir metodika}

Gravitacinis laukas matuojamas žemès paviršiuje ir priklauso nuo matavimo taško topografinès padèties koordinačiu ir aukščio - bei nuo giluminių masių pasiskirstymo. Siekiant išskirti iš stebimo lauko tą dali, kuri priklauso nuo tankių kitimo, stebimas laukas skaidomas i normalini, atspindinti idealiosios Žemès forma, ir anomaluji, kuris atspindi Žemès vidinès sandaros netolygumus. Anomalusis gravitacinis laukas išreiškiamas: $\Delta g=g_{s t}-\gamma_{o}+(0,3086-0,0419 \sigma) h$, čia $g_{s t}$ yra Žemès paviršiuje išmatuota sunkio jèga, $\gamma_{o}$ yra normalinė sunkio jèga, apskaičiuota idealiajai Žemei (sferoidui) ir priklausanti nuo geografinès platumos, (0,3086$-0,0419 \sigma) h$ - masių traukos tarp Žemès paviršiaus ir jūros lygio pataisa (Bouguer pataisa), čia $\sigma$ - uolienu tankis, o $h$ - reljefo aukštis. Kaip matyti iš formulès, vienintelis nežinomasis yra tankis, todèl sudarant anomaliojo gravitacinio lauko žemėlapius labai svarbu korektiškai ji izvertinti. Kuo tankis mažesnis, tuo didesnẻ reljefo įtaka ir atvirkščiai.

Lietuvos gravitacinio lauko nuotrauka 1:20000 masteliu atlikta 1958-1961 metais. Jos pagrindu sudarytas „Gravitacinio lauko žemèlapis“, Bouguer redukuotame laikant, $\mathrm{kad} 2,30 \mathrm{~g} / \mathrm{cm}^{3}$ tarpinio sluoksnio tankis pastovus, izolinijas vedant kas $2 \mathrm{mGal}$. Anomaliju tikslumas yra $\pm 0,40 \mathrm{mGal}$. $1997 \mathrm{~m}$. buvo sudarytas skaitmeninis Lietuvos Bouguer anomalijų žemėlapis, kuriame taip pat imta taikyti vienoda tarpinio sluoksnio tankio reikšmė [7]. Tai pakenkè sudaryto žemėlapio tikslumui, tačiau tuometinès techninès priemonès neleido efektyviai panaudoti sukauptos didžiulès gręžimo ir petrofizinių tyrimų medžiagos. Šios galimybès atsirado tik sukūrus skaitmeninę gręžinių informacijos duomenų bazę bei įdiegus GIS sistemas [8-10].

Tarpinio sluoksnio tankiu pasiskirstymo nustatymo metodika remiasi tam tikra 2 pav. pateiktų procedūru eiga.

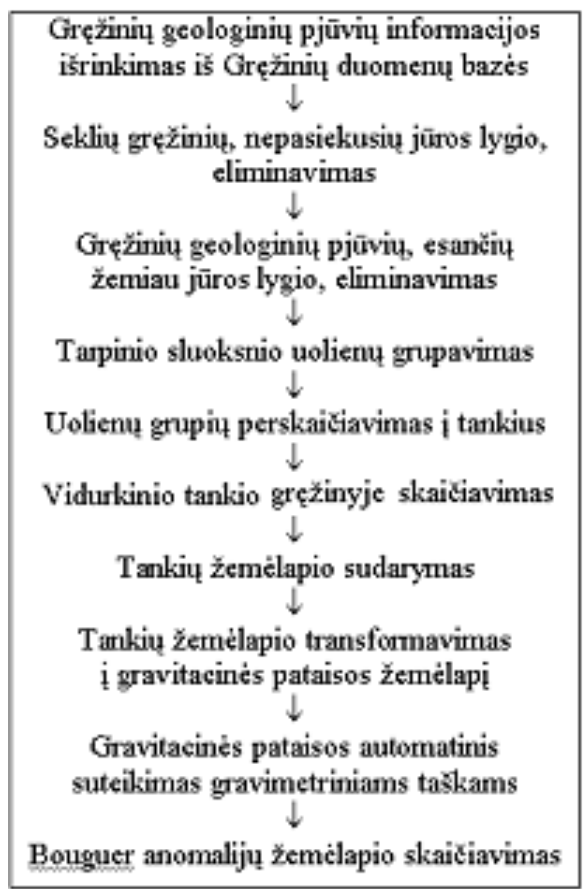

2 pav. Tankiu pasiskirstymo tarpiniame sluoksnyje ir Bouguer anomalijų skaičiavimo metodika

Fig 2. Flowchart of calculation of topography densities and Bouguer anomaly

Tyrimams naudotasi Geologijos tarnyboje sukurta Gręžinių duomenų baze, kuri yra sudètinè Valstybinès geologinès informacijos sistemos „Geolis“ dalis [8]. Gręžinių duomenų bazèje jau yra sukaupta informacijos apie daugiau kaip 32000 gręžinių. Skaičiavimams panaudota daugiau nei 293000 duomenų bazejje esančių gręžinių geologinių pjūvių irašų. Šie duomenys perkelti i MapInfo Professional programinę irangą, kurioje buvo atliekami pagrindiniai skaičiavimai. Darbui su duomenimis taikyta SQL (Structured Query Language) duomenu valdymo kalba. Darbo etapams automatizuoti MapBasic programavimo kalba sukurti ir panaudoti specialūs MapInfo paprogramiai. Taškinès informacijos interpoliacija atlikta naudojant Surfer for Windows programinę ịrangą.

Pirmuoju darbo etapu buvo automatiškai išeliminuoti seklesni nei jūros lygis gręžiniai (negilūs šuliniai, statybinių medžiagu paieškiniai gręžiniai ir pan.), (3 pav.). Iš viso skaičiavimams liko 13222 gilesni nei nulinis lygis gręžiniai. Antruoju etapu buvo atmesti visi geologiniai sluoksniai (taip pat sluoksniu dalys), esantys žemiau jūros lygio. Sudarytas visų aptinkamų uolienų, kurioms suteiktos tankio reikšmès, sąrašas. Apskaičiuotas kiekvieno gręžinio geologinio pjūvio, esančio virš jūros lygio, vidutinis tankis. Vidutinis tankis skaičiuotas pagal paprastą formulę: $\sigma_{v i d}=\left(\sigma_{1} h_{1}+\sigma_{2} h_{2}+\ldots\right) / h_{\text {bendras }}$, čia $\sigma_{i}$ yra $i$-ojo sluoksnio tankis, $h_{i}-i$-ojo sluoksnio storis, $h_{\text {bendras }}-$ sluoksnių storių suma. 


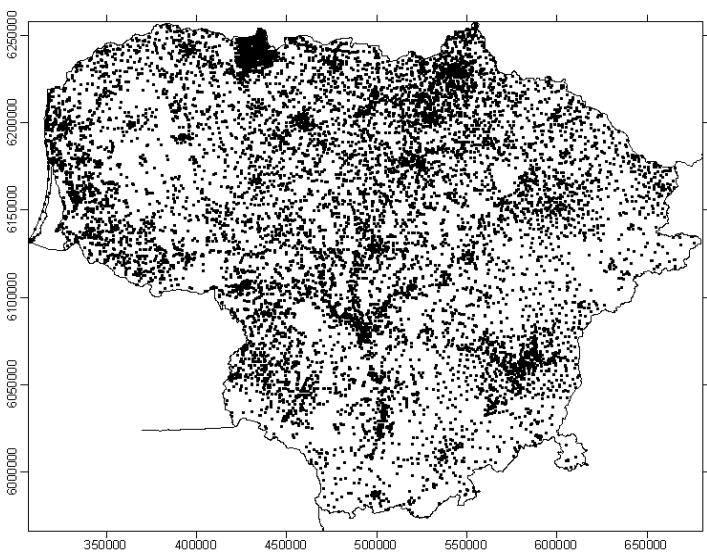

3 pav. Gręžinių, naudotu perskaičiuojant tarpinio sluoksnio tankius, žemèlapis (13 222 gręžiniai)

Fig 3. Locations of wells employed for calculation of topography densities (13 222 wells)

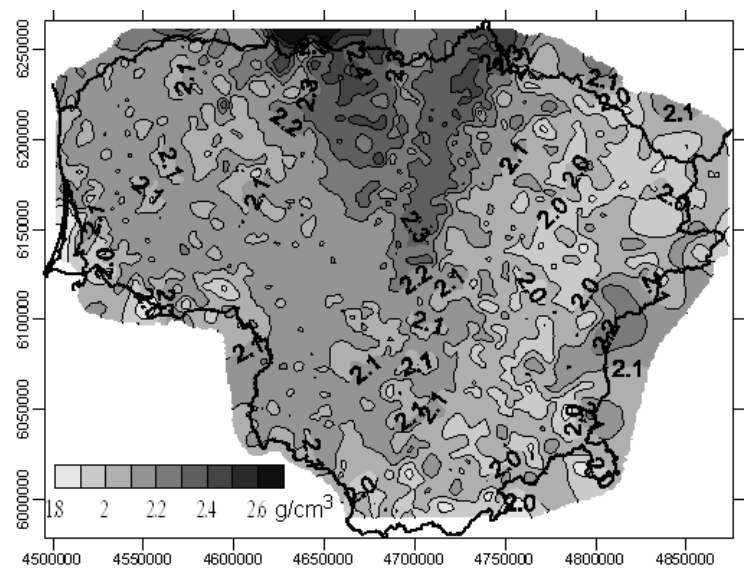

4 pav. Tarpinio sluoksnio tankių žemèlapis

Fig 4. Topography densities

Uolienų tankių reikšmės buvo gautos, panaudojant publikuotus [2] ir gausių geologiniu ataskaitu duomenis. Uolienu tankiai matuoti tik nedaugelyje gręžinių, tačiau dažniausiai pavienių uolienų grupių jie mažai skiriasi, todèl buvo sudarytas skirtingo geologinio amžiaus uolienų tankių katalogas pagal atraminius gręžinius. Šios reikšmès buvo priskirtos atitinkamiems sluoksniams ir tuose gręžiniuose, kuriuose tokie matavimai nebuvo atlikti. Tai leido automatiškai apskaičiuoti visu grę̌inių tarpinio sluoksnio vidutines tankio reikšmes. Atitinkamai remiantis šiais duomenimis, Surfer programa (minimalaus išlinkimo interpoliacijos metodu) sudarytas tankiu pasiskirstymo Lietuvos teritorijoje žemèlapis (4 pav.). Tankių pasiskirstymo žemėlapis pagal minėtają formulę $(0,3086-0,0419 \sigma)$ buvo perskaičiuotas i tarpinio sluoksnio gravitacinès pataisos žemèlapi (5 pav.).

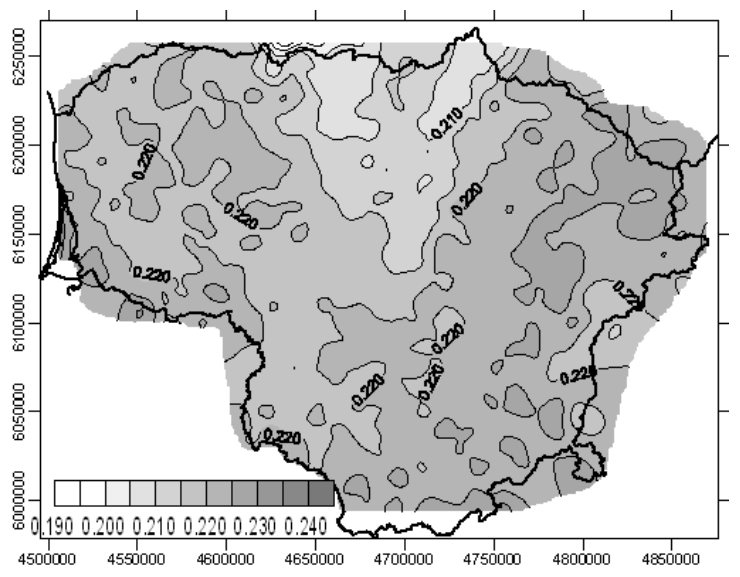

5 pav. Tarpinio sluoksnio gravitacinès pataisos žemèlapis

Fig 5. Gravity correction coefficient due to topography densities

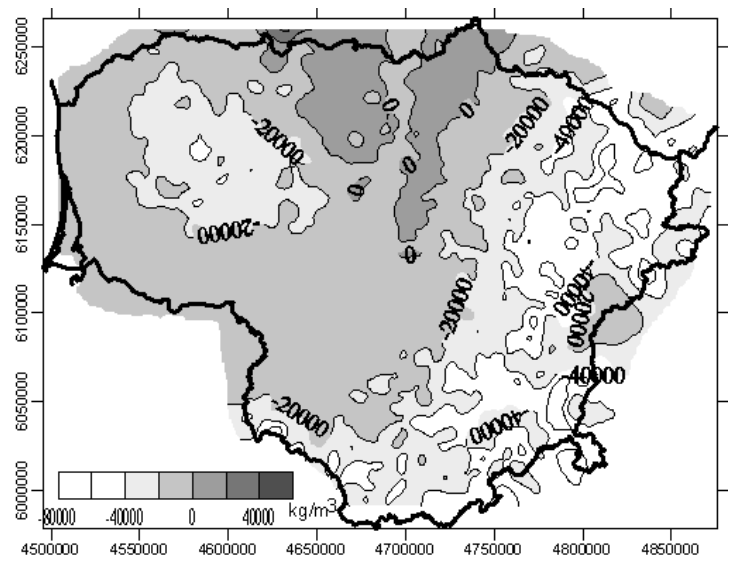

6 pav. Masių deficitas pagal naujaji modeli, palyginti su anksčiau naudotu tarpinio sluoksnio modeliu

Fig 6. Mass deficit of new density model (compared to old model)

Tiesiogiai gravitacinės pataisos žemėlapio negalima naudoti tikslinant senaji Bouguer žemèlapi dèl neišvengiamu (aproksimacijos) netikslumų sudarant skaitmeninius žemèlapius. Tiksliausia metodika yra kiekvienam gravimetriniam punktui suteikti gravitacinès korekcijos reikšmes iš korekciju žemèlapio ir naujai skaičiuoti Bouguer anomalijų žemèlapi. Reikšmès suteiktos MapInfo Vertical Mapper programa.

Tankiu skirtumas tarp naujo ir senojo modelių dar nerodo gravitacinio efekto masto, nes, esant plonam tarpiniam sluoksniui (t. y. topografiniam pažemèjimui), šis efektas (ir atitinkamai pataisa) yra minimalus ir atvirkščiai. Šiam efektui i̇vertinti sudarytas masių deficito pagal naujaji modeli, palyginti su anksčiau naudotu tarpinio sluoksnio modeliu, žemèlapis (6 pav.).

Naujas patikslintas Bouguer anomaliju žemèlapis buvo sudarytas naudojant Surfer programą Kriging interpoliacijos metodu (7 pav.). 


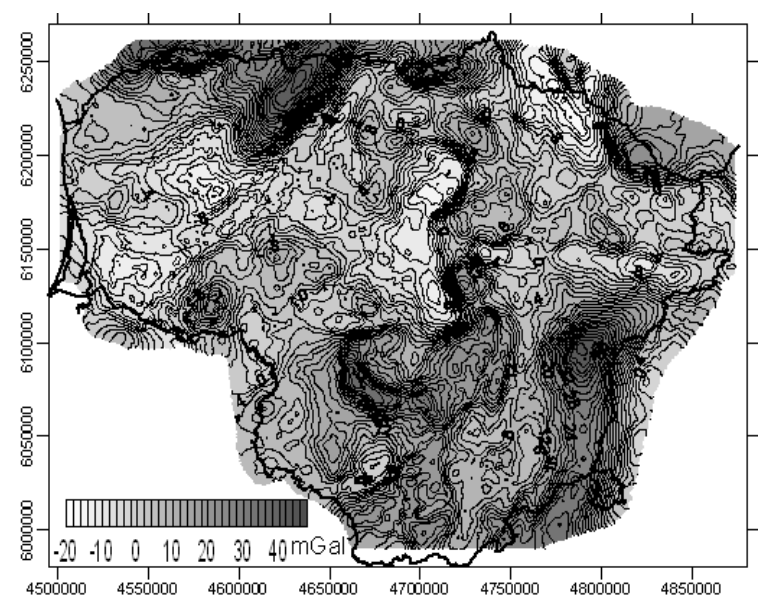

7 pav. Patikslintas Lietuvos Bouguer anomalijų žemėlapis Fig 7. New map of the Bouguer anomalies

\section{Tarpinio sluoksnio tankių pasiskirstymo nustatymas}

Sudarant Lietuvos Bouguer anomalijų žemėlapi taikytas vienodas $2,30 \mathrm{~g} / \mathrm{cm}^{3}$ tarpinio sluoksnio tankis. Kaip rodo petrofiziniai uolienų tyrimai, viršutiniai žemès sluoksniai Lietuvoje dažniausiai esti mažesnio tankio. Tarpinio sluoksnio tankiui apytiksliai įvertinti rekomenduojama L. L. Nettletono pasiūlytoji anomalijų laisvajame ore (ALO) ir topografijos linijinès regresijos metodika. Jos principas - kuo didesnis yra linijinès regresijos polinkio kampas, tuo didesnis reljefą sudarančių uolienu tankis [3]. Lietuvos gravitacinio lauko skaitmeniniame modelyje yra per 14000 stebejjimo taškų. Pateiktame grafike (8 pav.) matyti, kad koreliacija tarp ALO ir topografijos Lietuvos teritorijoje yra teigiama. Tiesinè priklausomybè aprašoma ALO = $0,094 * h+7,4$, čia ALO - anomalija laisvajame ore (mGal), $h$ - punkto aukštis virš jūros lygio (m). Koeficientas $0,094 \mathrm{mGal} / \mathrm{m}$ yra lygus $2 \pi G \rho$; kur $G$ yra universali gravitacijos konstanta $\left(6,67 * 10^{-11} \mathrm{SI}\right), \rho-$ tankis. Paprastas šios formulès sprendimas rodo, kad vidutinis tarpinio sluoksnio tankis yra $2,24 \mathrm{~g} / \mathrm{cm}^{3}$, taigi gerokai mažesnis nei naudotas sudarant Lietuvos Bouguer anomalijų žemèlapi.

Reikia pastebėti, kad ALO reikšmių svyravimas aukščiu diagramoje yra gana akivaizdus, tai reiškia, kad tankiai ivvairiose vietose gerokai skiriasi. Šiai problemai spręsti taikoma ta pati regresijos metodika, ir tokiu būdu galima gauti pavieniu blokų kiek detalesni tarpinio sluoksnio tankių modeli [3]. Tačiau tai taip pat gana grubus metodas, turint omenyje, kad Lietuvoje yra keliolika tūkstančių gręžinių, išgręžtu iki nulinio lygio.

Gręžimo duomenų susisteminimas ir apdorojimas GIS priemonemis leido sudaryti labai detalų tarpinio sluoksnio tankių pasiskirstymo žemèlapi. Pagal tarpinio sluoksnio tankių pasiskirstymą galima sąlygiškai išskirti tris rajonus, kurie gerai koreliuojami su Lietuvos geologinès sandaros ir reljefo ypatumais (4 pav.).

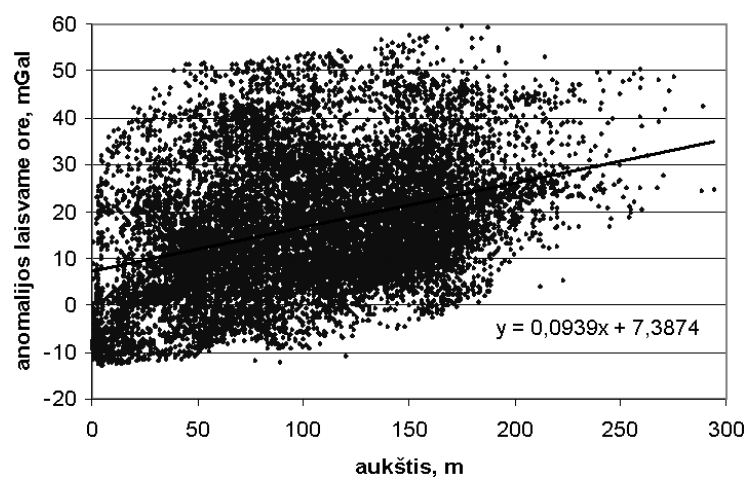

8 pav. Gravitacinių punktų aukščiu - anomalijų laisvajame ore grafikas ir tiesinè priklausomybė

Fig 8. Correlation between topography and free-air anomalies

Rytuose tarpinio sluoksnio tankiai yra mažiausi. Ši juosta, besitęsianti iš PPV i ̌̌ŠV, sutampa su Baltijos aukštumomis ir periferine lyguma. Minimalios reikšmès paaiškinamos keliomis priežastimis. Baltijos aukštumas sudaro Nemuno apledejjimo galinè morena su dažnais smèlingais mažesnio tankio intervalais. Be to, jos iš dalies sutampa su pokvartero paviršiaus neotektonine pakiluma. Pietuose tarpiniame sluoksnyje pokvartero uolienos - lengva kreida, rytuose vyrauja devono Upninkų - Šventosios smėlingosios nedidelio tankio uolienos. Vidutinis tarpinio sluoksnio tankis šioje juostoje kinta nuo $1,85 \mathrm{~g} / \mathrm{cm}^{3}$ iki $2,10 \mathrm{~g} / \mathrm{cm}^{3}$, retai siekia $2,20 \mathrm{~g} / \mathrm{cm}^{3}$. Minimalios reikšmès būdingos ašinei juostos zonai. Palyginti su kitais dviem rajonais, čia pastebima didesnè tankių diferenciacija.

Šiaurès Lietuvos centrinèje dalyje išskiriamas maksimalių tankių plotas, kuris plane yra trikampio formos. Ši forma koreliuojama su pokvartero paviršiaus geologiniu žemėlapiu [10]. Vakarinè riba sutampa su triaso uolienų atodanga, o rytiné - su tankių molingujųkarbonatinių (vakaruose) ir mažiau tankių smèlinguju (rytuose) devono sluoksnių sąlyčiu. Pastebėtina, kad šis laukas sudarytas iš dviejų didesnio tankio $(2,30$ $2,45 \mathrm{~g} / \mathrm{cm}^{3}$ ) plotu rytuose ir vakaruose, skiriamu mažesnio tankio juostos $\left(2,20-2,30 \mathrm{~g} / \mathrm{cm}^{3}\right)$, kuri sutampa su Vidurio Lietuvos neotektoninio įlinkio vakarine riba.

Lietuvos pietvakarinèje dalyje (didžiausias plotas) vyrauja $2,10-2,20 \mathrm{~g} / \mathrm{cm}^{3}$ tankio reikšmès. Tik pavieniu nedidelių ploteliu jos kiek mažesnès. Be to, pačioje vakarinejje šio lauko periferijoje išryškejja plona minimalaus tankio juosta išilgai Kaliningrado - Lietuvos valstybinès sienos ir jūros pakrantès. Reljefe ji atitinka pažemėjimą.

Bouguer pataisos koeficiento pasiskirstymas panašus i tarpinio sluoksnio tankių pasiskirstymą, tačiau koreliacija atvirkštinè (kuo didesnis tankis, tuo koeficientas mažesnis). Rytinès juostos šio koeficiento reikšmès kinta nuo 0,220 iki 0,225 , retai mažesnès. Šiaurès centrinio ploto šis koeficientas sumažeja iki 0,215-0,210 ir daugiau. Pietvakarinèje Lietuvos pusëje reikšmės kinta nežymiai, dažniausiai esti apie 0,220. 


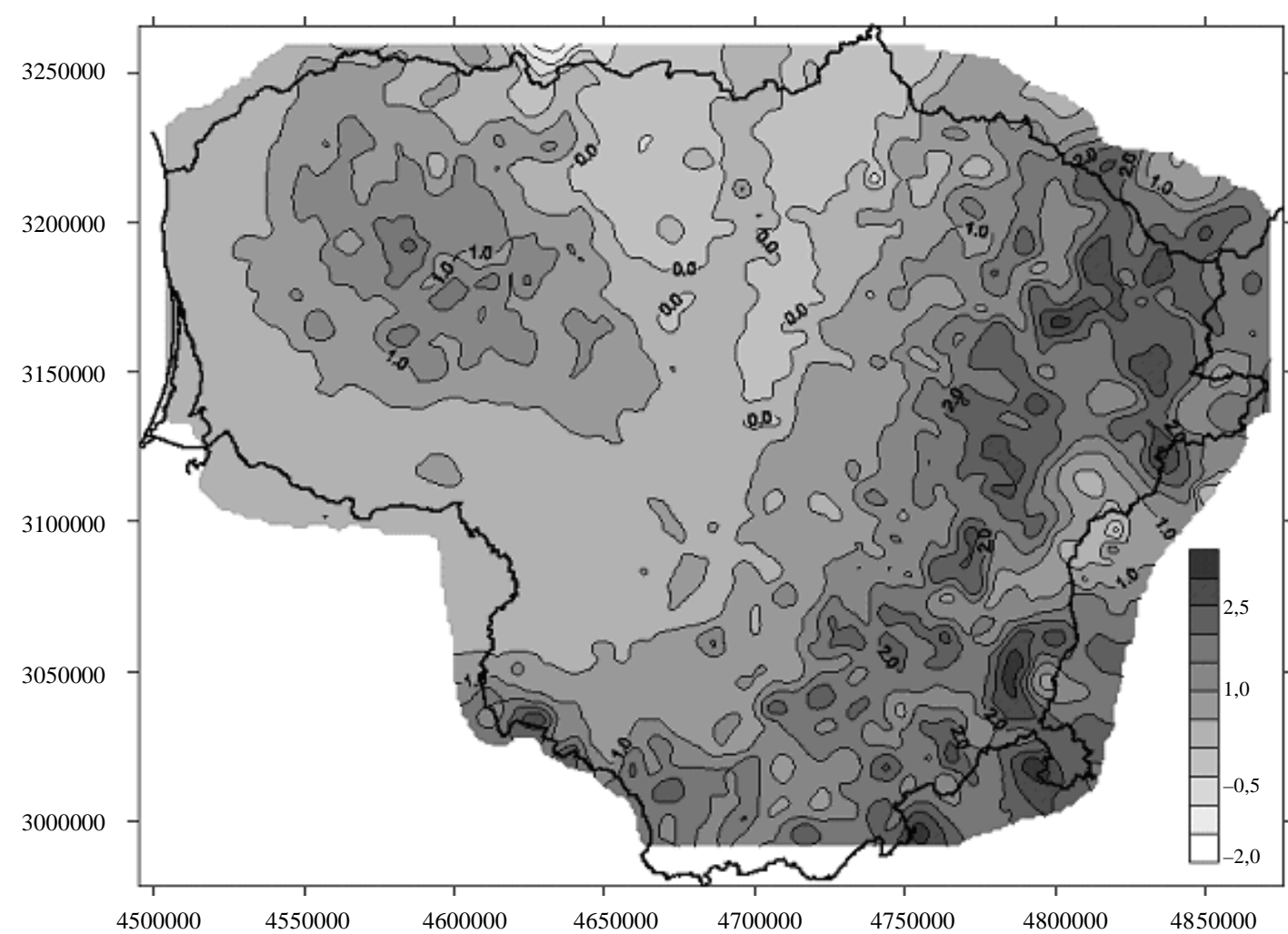

9 pav. Skirtumas tarp patikslinto ir ankstesnio Bouguer anomalijų žemèlapių

Fig 9. Difference between new and old models of Bouguer anomalies

Naujo modelio masių deficito žemėlapis, palyginti su anksčiau naudotu tarpinio sluoksnio modeliu, gerai atitinka nūdienos reljefo formas. Didžiausiasis deficitas būdingas Žemaitijos ir Baltijos aukštumoms. Žemaitijos aukštumų masių deficitas yra $-10000--20000 \mathrm{~kg} / \mathrm{m}^{2}$ (vietomis $-30000--40000 \mathrm{~kg} / \mathrm{m}^{2}$ ), o Baltijos aukštumu ašinejje dalyje šis deficitas siekia net iki -40000 $-50000 \mathrm{~kg} / \mathrm{m}^{2}$. Šiaurès Lietuvos centrinèje dalyje, kur kartografuojami didesni uolienų tankiai, masių skirtumas yra teigiamas (perteklinis), siekia iki $+10000 \mathrm{~kg} / \mathrm{m}^{2}$. Kitoje Lietuvos dalyje masių deficitas yra nuo 0 iki $-10000 \mathrm{~kg} / \mathrm{m}^{2}$.

\section{Patikslintas Bouguer anomalijų žemėlapis}

Patikslintas Bouguer anomalijų žemèlapis (7 pav.) iš pirmo žvilgsnio mažai tesiskiria nuo ankstesnès versijos, - sudaryto naudojant vienodo tankio tarpini sluoksni. Rytinèje Lietuvos dalyje (Rytų Lietuvos juosta) vyrauja gravitacinès anomalijos ŠŠR-PPV kryptimi, laukas ypač intensyvus pietryčiuose. Vakaruose (Vakarų Lietuvos granulitu masyvas) anomalijoms būdingas mozaikiškumas, lauko intensyvumas mažesnis, išskyrus pačią šiaurinę Vakarų Lietuvos dali, kuri atitinka Rygos plutono periferinę bazinę dali.

Skirtumų žemėlapyje labai aiškiai išryškejja senosios Bouguer anomalijų žemėlapio versijos trūkumai ( 9 pav.) Skirtumų žemėlapis savotiškai atitinka dabartini reljefą tai ir suprantama, nes reljefo aukštis daug lemia masių deficitą (tarp senojo ir naujojo modeliu) tarpiniame sluoksnyje. Tačiau svarbus yra ir tankių skirtumas.

Kaip ir tankio pasiskirstymo, matomi tie patys trys ortografiniai-geologiniai rajonai. Baltijos aukštumų rajone nustatytas maksimalus naujojo ir senojo modeliu neatitikimas - Bouguer anomaliju skirtumas siekia 12 mGal, o vietomis - netgi 2,5-3 mGal. Teigiamos skirtumų reikšmès rodo, kad naujajame Bouguer anomalijų žemėlapyje reikšmės kiek padidejo, tai susiję su mažesnèmis nei senajame modelyje tankio reikšmėmis, t. y. tarpinio sluoksnio dalis $\mathfrak{i}$ bendraji gravitacinị lauką sumažèjo.

Žemaitijos aukštumų pataisa yra $0,5-1 \mathrm{mGal}$, kai kur siekia iki 1,5-2 mGal.

Šiaurès Lietuvos centrinèje dalyje Bouguer anomalijų reikšmés sumažejo nuo 0 iki $0,5 \mathrm{mGal}$. Kitoje teritorijos dalyje pataisa yra nuo $0 \mathrm{iki}+0,5 \mathrm{mGal}$.

\section{Išvados}

1. Topografijos ir anomaliju laisvajame ore regresinè analizè rodo, kad Lietuvos Bouguer anomalijǔ žemėlapiui taikytas tarpinio sluoksnio tankis $2,30 \mathrm{~g} / \mathrm{cm}^{3}$ yra aiškiai per didelis, o tai lemia akivaizdžias gravitacinių žemèlapių paklaidas (Bouguer, geoido).

2. Lietuvoje nuosédinès dangos geologinè sandara virš nulinio lygio (t. y. tarpinis sluoksnis) yra labai kaiti, todèl tankių svyravimai taip pat akivaizdūs. Be to, tie pokyčiai netgi nedideliame plote gali būti labai ryškūs, 
todèl alternatyvios gravitacinio lauko interpretacijos metodikos (linijinè regresija blokais, fraktalinè analizè ir pan.) nèra pakankamai tikslios.

3. Turima gręžimo medžiaga (13 222 gręžiniai) leidžia kartografuoti tankio kitimus netgi nedideliuose plotuose. GIS priemonès atveria galimybes šią be galo gausią informaciją apdoroti ir išsamiam tarpinio sluoksnio tankių žemèlapiui sudaryti. Tankių žemėlapis labai siejasi su bendra geologine sandara ir šiuolaikiniu reljefu. Sąlygiškai išskiriami trys rajonai, kuriuose tankis kinta atitinkamai 1,85-2,1 g/ $\mathrm{cm}^{3}$ (Rytų ir Pietų Lietuva), $2,20-2,45 \mathrm{~g} / \mathrm{cm}^{3}$ (Šiaurès Lietuvos centrinè dalis) ir 2,10$2,20 \mathrm{~g} / \mathrm{cm}^{3}$ (pietvakariné Lietuvos pusè).

5. Sudarytas naujas Bouguer anomaliju žemėlapis bendrais bruožais nesiskiria nuo senosios versijos, tačiau lokaliosios pataisos yra gana akivaizdžios, Žemaitijos aukštumu jos siekia $0,5-1 \mathrm{mGal}$, Baltijos aukštumų - net 1-2 mGal (o vietomis - 2,5-3 mGal).

6. Pateikta metodika gali būti efektyviai taikoma ir kituose regionuose, kai sukaupta gausi gręžimo ir petrofizinių tyrimų medžiaga.

\section{Literatūra}

1. Baltrūnas, V. Stratigraphical subdivision and correlation of Pleistocene deposits in Lithuania (methodical problems). Vilnius: Institute of Geology, 2002, p. 74.

2. Ozolin, N. Physical properties of rocks of the Baltic Syneclise (Физические свойства пород Балтийской синеклизы). Рига: Зинатне, 1974. 138 с. (in Russian).

3. Rózsas, S. Local geoid determination using variable surface densities. Periodica Polytechnica Ser. Civ. Eng., 46(2), 2002, p. 205-212.

4. Holmes, M. L. and Johnson, H. P. Johnson, Upper crustal densities derived from sea floor gravity measurements: northern Juan de Fuca ridge. Geophys. Res. Lett., 20, 1993, p. 1871-1874.

5. Hisarli, M.; Orbay, N. Determination of crustal density at the atmosphere-crust interface of western Anatolia by using the fractal method. Journal of the Balkan Geophysical society, 5(1), 2002, p. 3-8.

6. LaFehr, T. R. Rock density from borehole gravity surveys. Geophysics, 48 (3), 1983, p. 341-356.

7. Korabliova, L.; Popov, M. Compilation of gravity and magnetic field digital maps of Lithuania at the scale of 1:200 000 (Lietuvos gravimetrinio ir magnetometrinio žemèlapio masteliu M 1:200 000 iskaitmeninimas). Lietuvos geologijos tarnybos ataskaita už 1996 metus. Vilnius, 1997, p. 21-23 (in Lithuanian).

8. Belickas, J. GEOLIS - geological information system. In: Science and Arts of Lithuania, Book 23 - Geosciences. Vilnius, 1999, p. 554-556.
9. Belickas, J.; Denas, Z. GIS-GEOLIS - as tools for geographic search of geological data. In: ICGESA -98 International Conference on GIS for Earth Science Applications, Ljubljana, Slovenia, 17-21 May 1998. Ljubljana, p. 251-252.

10. Šliaupa, S.; Dènas, Z.; Belickas, J. Integrated approach and application of GIS for management of geological data. Technika Poszukiwan Geologichnych. Geosinoptika $i$ Geotermia 6, 2003, p. 63-72.

Saulius ŠLIAUPA. Doctor Habil.

Institute of Geology and Geography. Dept of Background Geology, T. Ševčenkos g. 13, LT-03223 Vilnius, Lithuania (Ph +370 5 2104698, Fax +370 5 2104695), e-mail: sliaupa@geo.lt. Doctor Habil, Senior Research Associate at the Dept of Background Geology of Institute of Geology and Geography, Lithuania. Published 3 monographs, more than 100 scientific papers, participated in many intern conferences.

Research interests: regional geology, tectonics, geodynamics, lithology, petrophysics.

\section{Žydrūnas DE்NAS. MSc.}

Vilnius University. Dept of Geology and Mineralogy, M. K. Čiurlionio g. 21/27, LT-03101 Vilnius, Lithuania $(\mathrm{Ph}+3705$ 2398200, Fax +370 5 2398204), e-mail: z.denas@it.lt.

PhD student of the Dept of Geology and Mineralogy of the Vilnius University, Lithuania. Published several publications, participated in some intern conferences.

Research interests: application and development of GIS systems.

\section{Larisa KORABLIOVA. MSc.}

Geological Survey of Lithuania. Dept of Regional Geology, S. Konarskio g. 35, LT-03123 Vilnius, Lithuania

$(\mathrm{Ph}+3705$ 2330142, Fax +370 5 2336156), e-mail: larisa.korabliova@lgt.lt.

Senior geophysicist of Dept of Regional Geology of the Geological Survey of Lithuania. Published several papers and participated in intern conferences. Her research is focused on processing and interpretation of potential fields, with emphasis on the basement geology. 